DOI https://doi.org/10.15407/usim.2018.03.033

UDK 004:519.816:614.4

M.A. VORONENKO, PhD in Techn. Sciences, docent of the department of informatics and computer science of Kherson National Technical University of Ukraine, Berislavskoe highway, 24, Kherson, 73008, Ukraine, mary_voronenko@i.ua

\title{
EVENT MODEL FOR LOCALIZATION OF EMERGENCY SITUATIONS
}

The event model for the processes of epidemic emergency localization is constructed. The obtained calculations show that the expected gain of time for the localization of the epidemic situation, using the event model, according to the forecast data is 36-40 hours.

Keywords: epidemic situation, event model, localization, epidemic emergency.

\section{Introduction}

Technocratic way of the human civilization development in the nineteenth and twentieth centuries led to the increase of the emergencies of anthropogenic nature (accidents at nuclear power plants, fires and explosions in industrial facilities, transport accidents), which today make up $75-80 \%$ of the total number of emergency situations [1]. The number of natural disasters victims annually increases by an average of $6 \%$ [2]. According to the UN and WHO data, over the past 25 years, human losses due to the emergency situations are several times higher than losses during military operations [3]. Large-scale pollution of the water ecosystem is due to traffic accidents (on tankers, oil pipelines, oil platforms). Emissions into the biosphere often exceed its natural possibilities for self-purification and lead to the increase in the content of toxic elements - arsenic, cadmium, mercury, plumbum etc. in soils, natural waters and, consequently, in the flora and fauna.

\section{Problem statement}

Every year, the world ocean gets up to 30 million tons of oil and petroleum products, 6 million tons of phosphorus, 20 million tons of pesticides. At present, 5 nuclear submarines ( 7 nuclear reactors, 16 ballistic missiles, and two dozen torpedoes with nuclear warheads) have sunk into the world oceans - this creates uncontrolled disposal of radioactive waste $[4,5]$. The consequences of the major accidents, catastrophes, earthquakes, along with destruction, may be accompanied by outbreaks of infectious diseases, contamination of water intake systems and septic tanks, the breakthrough of sewage networks, the destruction of natural ecosystems and other unsanitary phenomena [3]. Every 20 seconds in the world one child dies as a result of improper water purification, which currently does not provide about 2.6 billion people on the planet [5]. On Fig. 1. there is a map of the ecological situation and state of water resources in Ukraine [4].

It is known that $1 \mathrm{~m}^{3}$ of wastewater destroys $50 \mathrm{~m}^{3}$ of fresh water from surface sources, which leads to allergic diseases on the epidemic scale. In reservoirs, where more than $70 \%$ of the population of Ukraine receive drinking water, $40 \%$ of untreated agricultural and industrial waste water is disposed. Water can become a chemical solution, dangerous not only for use, but also for use in gen- 


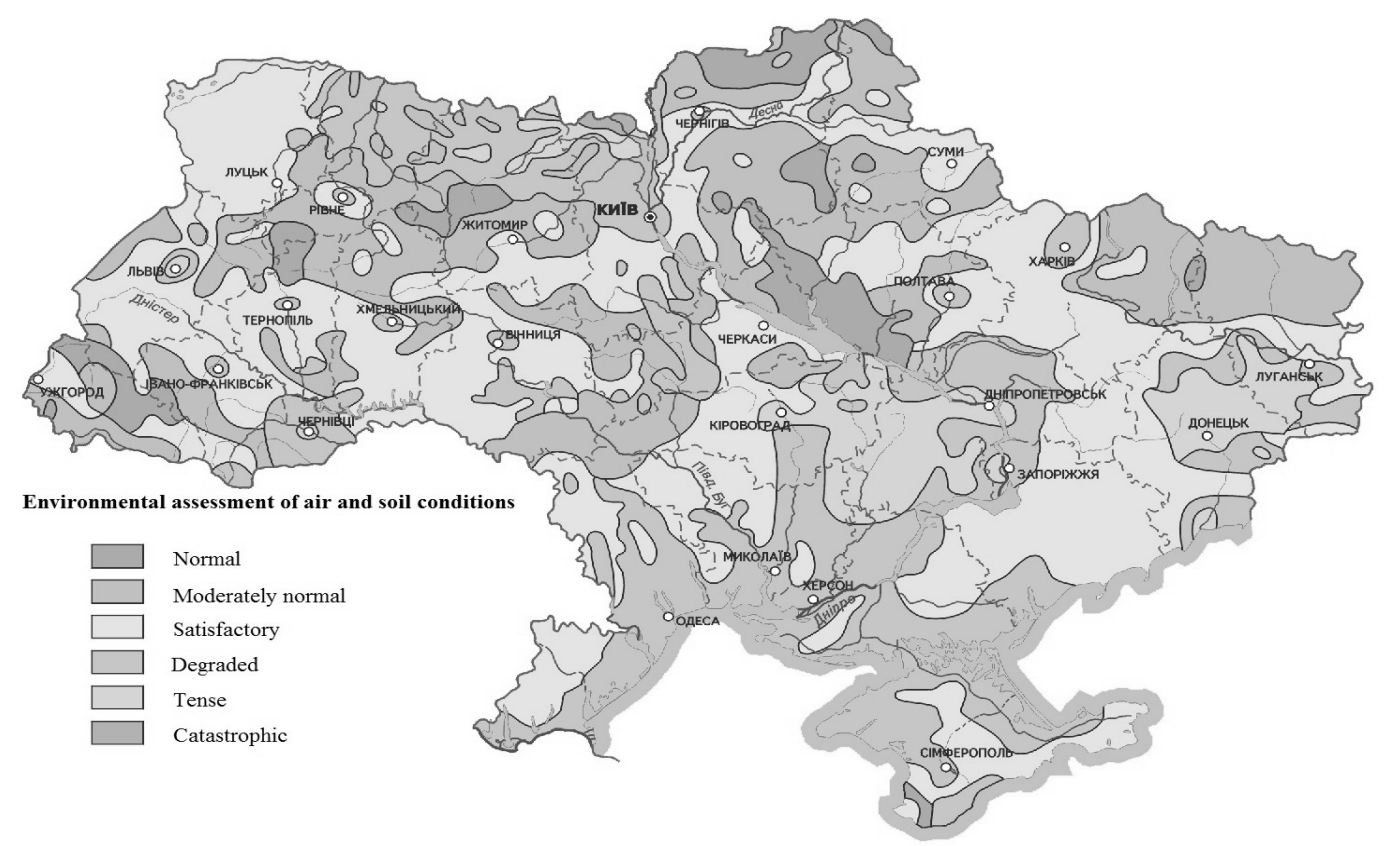

Fig. 1. Map of the ecological situation and state of water resources in Ukraine

eral [6]. The outbreak of infectious diseases, in connection with which at least 1,3 million people die each year $[6,7]$, constitute a serious threat.

The operative and coordinated actions of the regional level authorities requires the creation of a controlling influence over a period of time after which it makes sense to implement them. The proactive nature of these actions can be achieved by using the prediction principle [7]. Therefore, it is necessary to develop the models of the region functioning in conditions of epidemic situations and algorithms of the effective regional resources management. The scientific basis for dissertation researches were the works of such scientists as: Stennin A.A., Vasyukhin M.I., Zade L.A., Mikoni S.V., Nogin V.D., Petrov E.G., Saati T.L., Fishburne R.S., Larichev O.I. etc. The works of these and other authors have created methodological and theoretical preconditions for the research work. Among the works on the epidemic emergency localization and those dealing with the processes related to the prediction and optimization of the epidemic emergency, stands the fundamental three-volumed monograph by Goryev L.M., Doroguntsov S.I. and Hvesyk M.A. "Op- timization of ecoareas" [4]. Created by authors adequate mathematical models of related processes let simulate the epidemic process.

Computerization of simulation systems allow finding efficiently the best options for the functioning and prevention of the extra situations occurrence. But in order that the simulation systems could be used as a part of event model, it is necessary to simplify the numerical solution of differential equations describing epidemic processes, and make it more useful for practical implementation.

The research on the effective management in the conditions of the epidemic emergency shows that in this area practically no method of designing, there are no models for forecasting the development of the situation, resulting in a decisionmaking process delayed or misplaced. Leaders in making managerial decisions mainly use their experience and intuition, but do not see the picture as a whole. Therefore, carrying out scientific researches on the improvement and computerization of decision-making processes in the epidemic emergency environment, the development of models, methods, algorithms, programmes and 


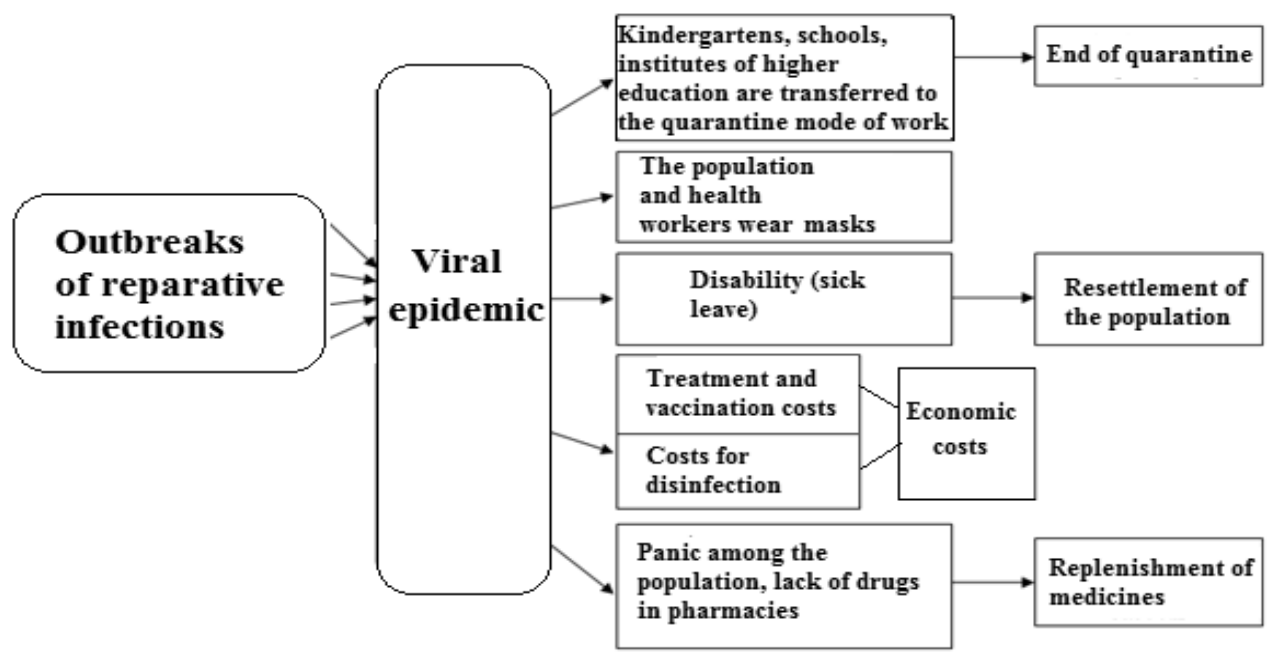

Fig. 2. Map of events during protective measures

information technologies is an actual scientific and technical task.

The objective of the article. The purpose of this work is to create a model of epidemic processes, suitable for further application of situational control methods.

\section{The main material}

The reason for the ES, which is typical for the regions of Ukraine, is often the epidemic of infectious diseases. The main tasks during the epidemic are:

- prediction of the possibility of mass infections and other epidemic situations;

- creation of the medicine reserves, medical equipment, pills and other materials;

- organization of the events (lectures, practical classes) with medical staff in order to ensure readiness for work in conditions of the epidemic and other mass diseases;

- rapid reaction to the ES, including an assessment of the nature and extent of possible consequences of such events, prompt notification of authorities and the population about the threat and the facts of the emergence of the ES.

Managing actions should be based on both current and projected states of regional components. Depending on how the situation arises, the required values of the control effects can vary.
Therefore, there is a need for their multiple formation in a shorter time interval, taking into account the reports of changes in the situation in the region. In practice, this means an operational redistribution of resources to take the necessary steps in the process of clarifying the situation. The considered approach allows us to decompose each major task of decision-making in the conditions of the epidemic situations for the tasks sequence, formulate the results of periodic monitoring of the state and the regional components. Each problem is solved by performing relatively simple functional tasks.

The condition of the population during the epidemic is determined by a number of internal and external factors. Internal factors include the natural ability of people to counter adverse environment, which depends on age and psychophysiological characteristics, from training and readiness to act in the conditions of the epidemic. External factors include protective measures and disinfectant, or quarantine, directed from the outside. The cndition of the population is estimated by the level of sanitary losses: irreversible, heavy, medium and light. Estimation of losses directly depends on the results of the implementation of protective measures.

The development of the epidemic consists of different periods - threatening, crisis, post-crisis. 
The implementation of protective measures is determined by these periods of the development of the epidemic (Fig. 2). During the menacing period, preventive measures are taken, during the crisis period, rescue measures are carried out, in the post-crisis period - restorative measures.

The primary uncertainty and the variability of these characteristics are reduced with the help of scenario descriptions of the possible alternatives to the development of the ES. Experienced experts, who establish a limited number of permissible states of regional components and their interconnections in threatening, crisis and post-crisis periods, are involved in the development of potentially implemented alternatives. This ensures the necessary completeness of the description of the processes under consideration, with sufficient account of their characteristics for setting and solving the tasks of supporting decision-making on regional protection.

\section{The event model}

Consider the general procedure for describing alternatives to the development of an epidemic ES. Formalized description of the development processes of the ES is based on the establishment of system-causing causal relations between the components of these processes. Since these causal relations lead to a change in the states and properties of the interacting components, we will use the casual approach to determine them. Under the event we will understand the jump-like change in the properties of the component, in which it passes into a qualitatively new state. Each event occurs under the influence of mutually determined external and internal factors. External factors are manifested in the form of protective measures or impressive influences, internal - in the form of the ability to resist adverse environments or to produce spectacular actions. The results of the interaction of external and internal factors - this is the successive-parallel events, which constitute the development of epidemic ES. Each of these events implements a certain causal connection between the state-cause and one of the possible stateeffects of the interacting components (Fig. 3). In case-by-case approach, the processes under consideration can be presented in general terms $\sum=(C, P)$, where the set of vertices $C$ corresponds to the state of components of the ES components, and the set of arcs $P$ - events occurring when these states change. Each component in any state can generate a series of alternative events that determine the possible variants of new states of the same or other components. Components of the ES form a mutual triad $C=\{V, X, Z\}$, where $V=U_{i} V_{i}$ - plenty of sources of striking influences, $X=U_{j} X_{j}$ - set of objects of defeat and protection (people), $Z=U_{r} Z_{r}$ - a set of resources for protective measures. Changes in the states of these components occur under the influence of external and internal factors $P=\{U, R\}$, where $U$ - the set of disjoint subsets of the impressive influences $W$ and protective measures $M$, and $R$ is the set of internal factors of defeat $Q$ and protection $F$. In this case, the factors $W$ and $Q$ cause the transitions of the components in the undesirable states, and the factors $M$ and $F$ are in the desired states. In Figure 3 for a plurality of $U$ protective actions are denoted by "+", and the impressive actions "-"; for $R$, the resistance of the infection is indicated by "+" (healthy), and infection "-" (ill).

Building a model $\sum=(C, P)$ is a difficult formalized process that is carried out in stages according to the allocated periods of the development of the epidemic emergency plan, the normative data on the sources of the impressive influences and resources of protective measures, methods of constructing trees of failures, prediction of the consequences of the impressive influences and expert assessments. At the first stage, the indicators determining the development of the ES in a menacing period are structured. At first, with the help of experienced experts, the internal structure and external environment of the given region are studied. The alternative $V i$ sources are identified, the most difficult scenarios are developed for possible manifestations of the impact, as well as the potentially vulnerable classes of the population $X_{j}$ are identified and the resources of $Z_{r}$ are involved. Indicator $V_{i}^{H 1}$ characterizes the ability of sources $i$ to spread at the beginning of a threatening period. Indicators $X_{j}^{H 1}$ and $Z_{r}^{H 1}$ reflect the 


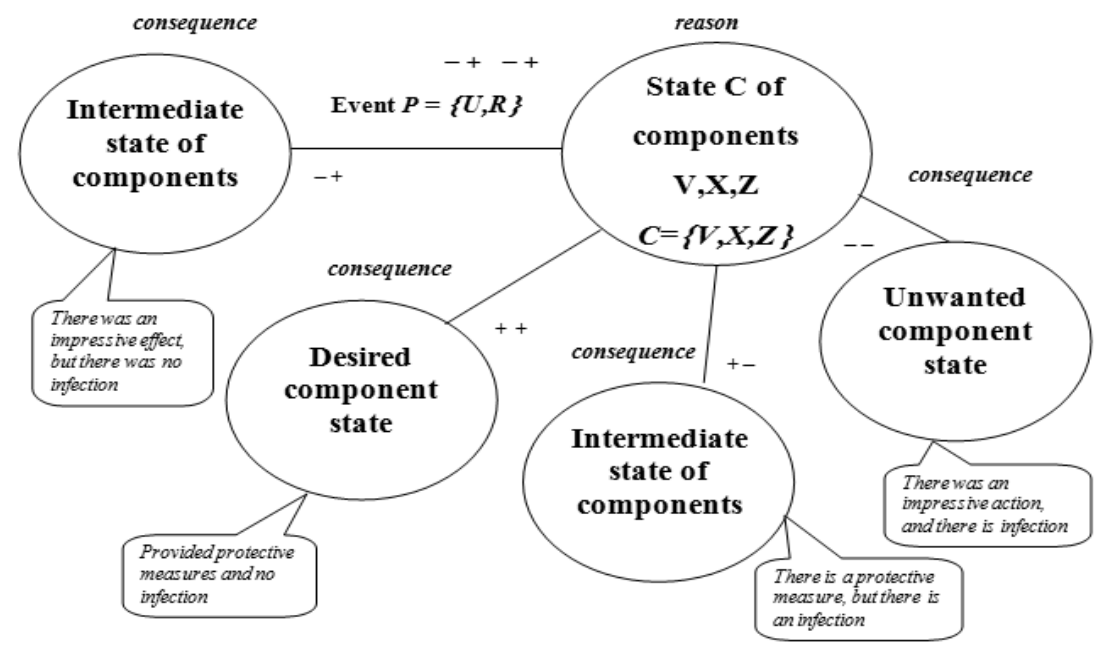

Fig. 3. Description of alternatives to the development of epidemic ES

\begin{tabular}{|c|c|c|c|}
\hline \multirow[b]{2}{*}{$\begin{array}{c}\text { Sources } \\
\qquad V i\end{array}$} & $\begin{array}{l}\text { 1- The menacing } \\
\text { period }\end{array}$ & $\begin{array}{l}2-\text { The crisis } \\
\text { period }\end{array}$ & $\begin{array}{l}3 \text { - The post-crisis } \\
\text { period }\end{array}$ \\
\hline & $V_{i}^{*_{1}} \longrightarrow V_{i}^{*_{1}} \longrightarrow$ & $V_{i}^{k_{2}} \longrightarrow V_{i}^{k_{2}} \longrightarrow$ & $V_{i}^{k_{z}} \longrightarrow V_{i}^{\alpha_{z}}$ \\
\hline $\begin{array}{c}\text { People } \\
X_{j}\end{array}$ & $X_{j}^{\kappa_{2}} \longrightarrow X_{j}^{\kappa_{2}} \longrightarrow$ & $X_{j}^{\kappa_{2}} \longrightarrow X_{j}^{\alpha_{2}}$ & $\longrightarrow X_{j}^{\kappa_{z}} \longrightarrow X_{j}^{\kappa_{z}}$ \\
\hline $\begin{array}{c}\text { Resource } \\
Z_{r}\end{array}$ & $Z_{r}^{\kappa_{1}} \longrightarrow Z_{\nu}^{\kappa_{1}} \longrightarrow$ & $Z_{r}^{k_{2}} \longrightarrow Z_{r}^{\alpha_{2}}$ & $Z_{r}^{\alpha_{z}} \longrightarrow Z_{r}^{\alpha_{z}}$ \\
\hline & $\begin{array}{c}\text { Phase of preventive } \\
\text { measures }\end{array}$ & $\begin{array}{c}\text { Phase of rescue } \\
\text { measures }\end{array}$ & $\begin{array}{c}\text { Phase of recovery } \\
\text { measures }\end{array}$ \\
\hline
\end{tabular}

Fig. 4. Event Model for the Development of the Epidemic Emergency

state of the people (possible human losses $j$ ) and the availability of necessary resources $r$, respectively. The states of sources, people and resources in different periods of the ES development are shown in Fig. 4.

Thus, the development of the situation in time will be characterized by the sequence of such indicator tuples for the initial condition estimations:

$\left(V_{i}^{\mu_{1}}, X_{j}^{H_{1}}, Z_{r}^{H_{1}}\right)$ - at the beginning of the threatening period;
$\left(V_{i}^{\kappa_{1}}, X_{j}^{\kappa_{1}}, Z_{r}^{\kappa_{1}}\right)-$ at the end of the threatening period;

$\left(V_{i}^{H_{2}}, X_{j}^{H_{2}}, Z_{r}^{H_{2}}\right)$ - at the beginning of a crisis period;

$\left(V_{i}^{\kappa_{2}}, X_{j}^{\kappa_{2}}, Z_{r}^{H_{2}}\right)$ - at the end of the crisis period;

$\left(V_{i}^{H_{3}}, X_{j}^{H_{3}}, Z_{r}^{H_{3}}\right)$ - at the beginning of the postcrisis period;

$\left(V_{i}^{\kappa_{3}}, X_{j}^{\kappa_{3}}, Z_{r}^{\kappa_{3}}\right)$ - at the end of the post-crisis period. 


\section{Decision Making Algorithm}

Let's try to follow the way in which an expert works in a particular area. Examples of experts are the examining physician, the sanitary doctor who studies the living conditions of the population, or an employee of the Ministry of Emergencies, who manages the process of eliminating the epidemic ES. The diagram of the sequence of actions in the process of supporting the adoption of managerial decisions in the detection of epidemic ES is presented in Fig. 5.

Evaluating the effectiveness of decision-making helps to understand the strengths and weaknesses, the compliance with the original plan, or leads to the achievement of the planned results, and what changes should be added in time to the process in order to make it more effective. The effective using of the event model an be proved by comparing the quality of decisions that are taken by the head without it and with its use.
Experimental studies show that the loss of time for the formation of informational training management decision is half the time from the total, allocated for preparing decision-making, and this is unacceptable while lack of time. We select a set of elementary operations that are performed when localizing an epidemic ES. The ultimate goal is achieved in a phased manner, through the sequence of execution of all elementary operations (tasks). This approach allows us to present our actions in the form of an algorithm that includes the following operations:

1 - to accept information about the beginning of the epidemic;

2 - get the preliminary answer from the laboratory ( 2 hours);

3 - assess the availability of required resources according to the laboratory report and notify the relevant services (12 hours allocated);

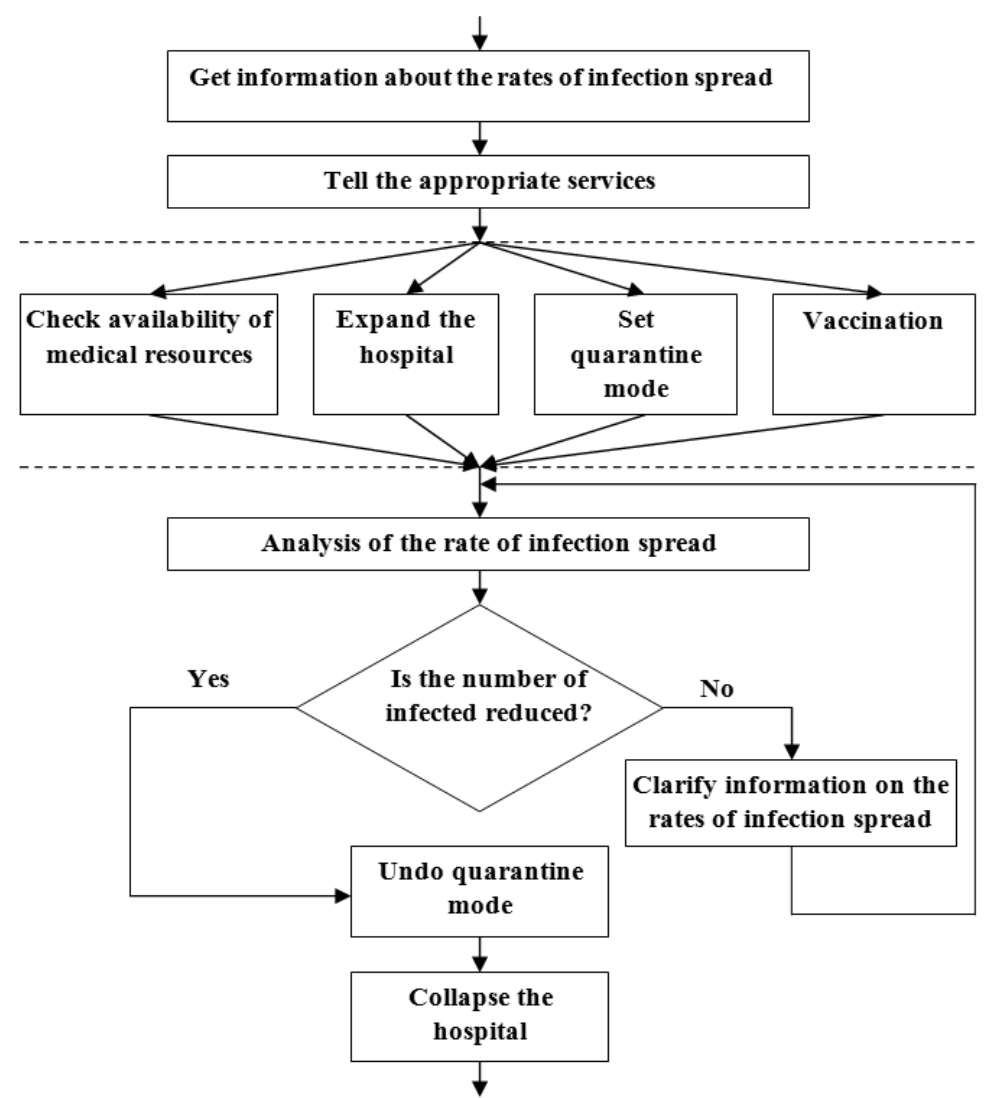

Fig. 5. Scheme of the sequence of actions in the localization of pandemics and viral epidemics 


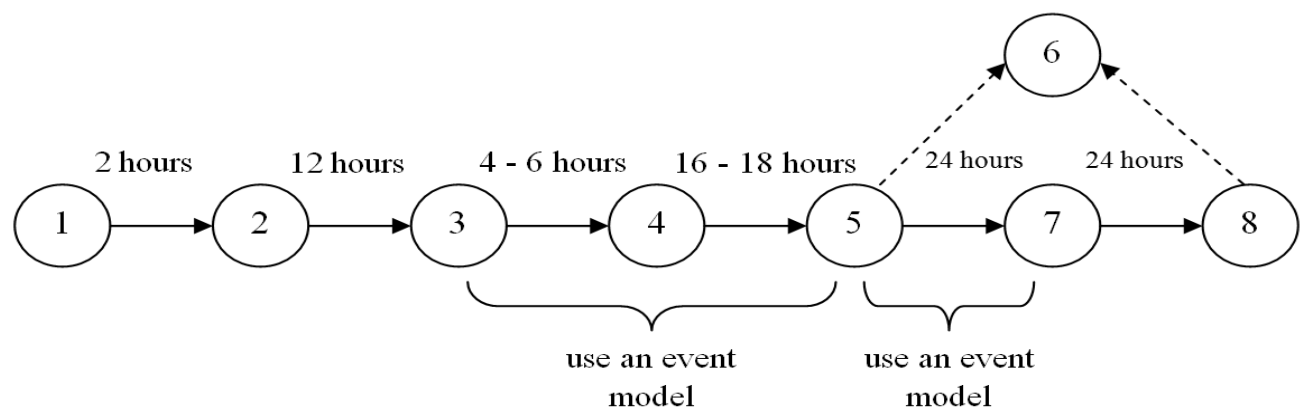

Fig. 6. Standards of time for localization of the epidemic

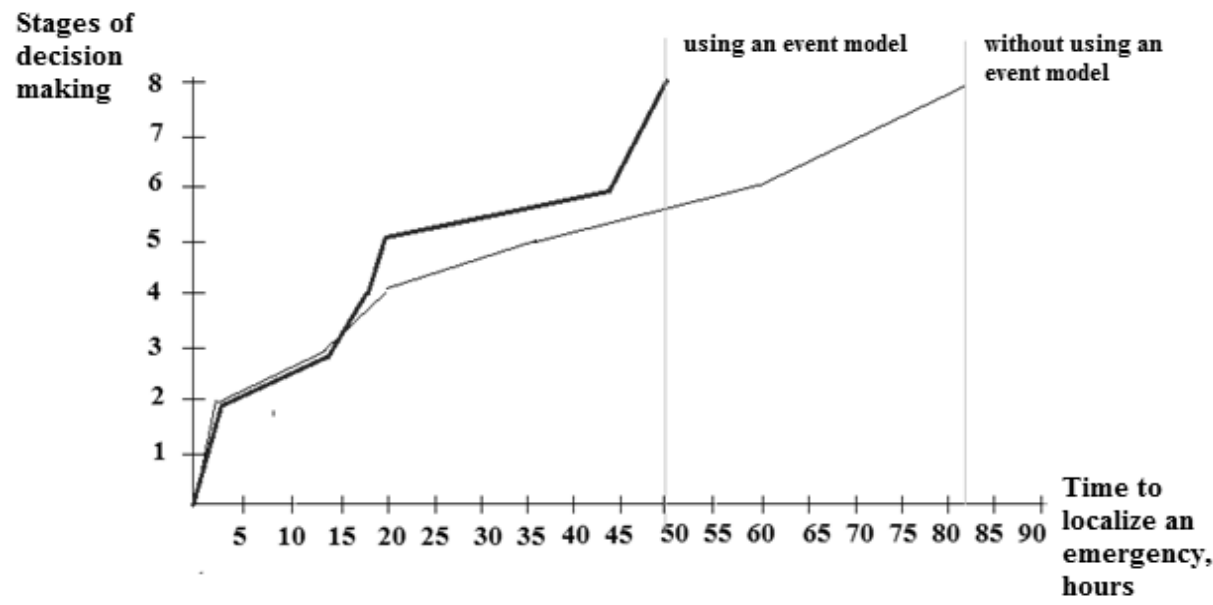

Fig. 7. Evaluating the effectiveness of decision-making

4 - assess and predict the levels of infection, the rate of infection and determine the type of emergency (from 4 to 6 hours);

5 - analyze the level of hazard of the ES, calculate the amount of resources for its localization and prepare the appropriate set of measures (it takes 16-18 hours);

6 - to bring the necessary medical resources (allocated 48 hours);

7 - analyze the current information received and make the necessary calculations based on it (24 hours);

8 - get information on reducing the number of patients (24 hours).

\section{Results and Discution}

Data about time limits are taken in accordance with the comprehensive plan [3]. Any epidemic
ES develops under the exponential law (due to the increase in the number of contacts and the admission of related infections), so it is very important to win time until the extent of distribution has not gone out of control. We see, as shown in Figure 6, that the total time for the localization of the epidemic ES without the use of the event model is: $2+12+4(6)+16(18)+24+24=86(90)$ hours. When the health manager makes decision, following the proposed scenarios of the event model, the path from the 3 rd to the 5 th point, we believe, can be reduced by 4 times and will take no longer than 20 (24) hours, and 6 hours (2 hours for information, 3 hours for analysis and 1 hour for decision making). The same thing, as we forecast, will be on the interval from the 5 th to the 7 th point instead of 24 hours -6 . Foreseeable assessment of the effectiveness of localization of the ES is presented in Fig. 7. Thus, we hope to get the total 
time for the localization of the epidemic emergency situation using the event model: $2+12+6+$ $+6+24=50$ hours. Expected winning time is 36-40 hours. This time can be used to prevent the occurrence of concomitant infections, to reduce the number of contacts and spreading panic among the population.

\section{Conclusion}

An event model for the development of the epidemic is obtained, taking into account the causal relations between the regional components. Solutions to such tasks include the use of situational management and new information technologies.
An evaluation of the effectiveness of the developed model is carried out. The obtained calculations show that the expected gain of time for the localization of the ES according to the forecast data is 36-40 hours.

Prospects for the use of research results. In further research, the authors plan to develop an appropriate information technologies and software that, using the event model, will reduce the burden on OPR under uncertainty, optimize work on the elimination and prevention of emergency situations development, harmonize the work of medical and environmental services, reduce the amount of localization costs on emergency situations.

\section{REFERENCES}

1. Zaychenko, D., 2014. "Analysis of emergency situations of technogenic and natural character". Emergency situation. 3, pp. 37-38.

2. Arkhipova, N.I., Kulba, V.V., 2012. Management in emergency situations. Ross.Gos.humanit. nut-t. M., 316 p.

3. Emergency Situations Analysis in Ukraine for the 4th quarter of 2015, [online] Available at: $<$ http://www.mns.gov.ua/quater/?m=B3> [Accessed 10 Oct. 2016].

4. Goryev, L.M., Doroguntsov, S.I., Hvesyk, M.A., 1997. Optimization of ecoareas. Kiev, Naukova dumka, 542 p.

5. Voronenko, M.A., 2010. "Models of support of decision-making in sanitary-epidemic control systems in the region". Intelligent systems of decision-making and problems of computational intelligence: Materials of the international scientific and practical conference. Yevpatoria, May 17-21, 2010. Kherson: ed. In KhMI, T.2, pp. 239-243.

6. Voronenko, M.A., Abramov, G.S., 2014. "The search model for rational solution of resource distribution". System technologies, 6 (95), pp.125-129.

7. Voronenko, M.A., 2014. "Modeling the influence of natural and anthropogenic factors on the formation of the chemical composition of river waters". Problems of information technologies. Kherson: ed. Kherson National Technical University, 16, pp. 86-91.

Received 17.10.2018

M.О. Вороненко, канд. техн. наук, доцент кафедри інформатики та комп'ютерних наук, Херсонський національний технічиий університет, Бериславське шосе, 24, Херсон, 73008, Україна, mary_voronenko@i.ua

\section{ПОДІЕВА МОДЕЛЬ ЛОКАЛІЗАЦІЇ НАДЗВИЧАЙНИХ СИТУАЦІЙ}

Вступ. Технократичний шлях розвитку цивілізації в дев'ятнадцятому і двадцятому століттях спричинив збільшення кількості надзвичайних ситуацій антропогенного характеру (аварії на атомних електростанціях, пожежі і вибухи на промислових об'єктах, транспортні аваріі), які на сьогодні складають 75-80 відсотків від загальної кількості надзвичайних ситуацій. Число жертв стихійних лих щорічно збільшується в середньому на 6 відсотків. Згідно з даними ООН і ВOO3, за останні 25 років людські втрати через надзвичайні ситуації в кілька разів перевищують втрати під час воєнних дій. Масштабне забруднення водних екосистем обумовлено дорожньо-транспортними подіями (на танкерах та нафтових платформах). Викиди в біосферу перевищують природні можливості для самоочищення і призводять до збільшення вмісту токсичних елементів - миш'яку, кадмію, ртуті ті інших у грунтах, природних водах i, отже, у флорі і фауні.

Мета статті. Створити модель епідемічних процесів, що підходять для подальшого застосування ситуаційних методів контролю.

Методи. При побудові моделей епідемічних процесів використовуються методи аналізу, ситуаційного управління і математичної статистики. 
Результат. Будь-яка епідемічна надзвичайна ситуація розвивається за експонентним законом (через збільшення кількості контактів і приєднання супутніх інфекцій), тому важливо виграти час, поки ступінь поширення не вийшов з-під контролю. Загальний час, відведений на локалізацію епідемічної надзвичайної ситуації без використання подієвої моделі становить $2+12+4(6)+16(18)+24+24=86$ (90) годин. Якщо особа, що приймає рішення, слідує запропонованим сценаріями подієвої моделі, шлях з третього по п'ятий пункт може бути зменшений в чотири рази і становить шість годин (дві години на сбір інформації, три години для іiі аналізу і одну годину на прийняття рішення) замість 20-24 годин. Те ж саме відбуватиметься на інтервалі 3 п'ятого по сьомий пункт - замість 24 годин - шість. Таким чином загальний час, відведений на локалізацію епідемічної аварійної ситуації з використанням подієвої моделі дорівнює $2+12+6+6+24=50$ годин . Очікуваний час виграшу 36-40 годин. Його можна використовувати для запобігання виникненню супутніх інфекцій, зменшення кількості контактів і запобігання поширенню паніки серед населення.

Висновок. Розроблено подієву модель розвитку епідемічної надзвичайної ситуації з урахуванням причиннонаслідкових зв'язків між регіональними компонентами. Розв'язання таких задач включає в себе використання ситуаційного управління і нових інформаційних технологій. Проведено оцінку ефективності розробленої моделі. Отримані розрахунки показують, що очікуваний приріст часу на локалізацію надзвичайної епідемічної ситуації, згідно прогнозованим даним, становить 36-40 годин.

Ключові слова: епідемічна ситуація, подійна модель, локалізація, вірусна епідемія.

M.A. Вороненко, канд. техн. наук, доцент кафедры информатики и компьютерных наук, Херсонский национальный технический университет, Бериславское шоссе, 24, Херсон, 73008, Украина, mary_voronenko@i.ua

\section{СОБЫТИЙНАЯ МОДЕЛЬ ЛОКАЛИЗАЦИИ ЧРЕЗВЫЧАЙНЫХ СИТУАЦИЙ}

Введение. Технократический путь развития цивилизации в девятнадцатом и двадцатом веках привел к увеличению числа чрезвычайных ситуаций антропогенного характера (аварии на атомных электростанциях, пожары и взрывы на промышленных объектах, транспортные аварии), которые сегодня составляют 75-80 процентов от общего числа чрезвычайных ситуаций. Число жертв стихийных бедствий ежегодно увеличивается в среднем на 6 процентов. Согласно данным ООН и ВО3, за последние 25 лет человеческие потери при чрезвычайных ситуациях в несколько раз превышают потери во время военных действий. Крупномасштабное загрязнение водных экосистем обусловлено дорожно-транспортными происшествиями (на танкерах, нефтепроводах, нефтяных платформах). Выбросы в биосферу часто превышают естественные возможности самоочищения и приводят к увеличению содержания токсичных элементов - мышьяка, кадмия, ртути и других в почвах, природных водах и, следовательно, во флоре и фауне.

Цель. Создать модель эпидемических процессов, подходяшую для дальнейшего применения ситуационных методов контроля.

Методы. При построении моделей эпидемических процессов используются методы анализа, ситуационного управления и математической статистики.

Результат. Любая эпидемия ЭС развивается по экспоненциальному закону (увеличение числа контактов и присоединение сопутствующих инфекций), поэтому важно выиграть время, пока степень распространения не вышла из-под контроля. Общее время, отведенное на локализацию эпидемии чрезвычайной ситуации без использования событийной модели составляет: $2+12+4(6)+16(18)+24+24=86$ (90) часов. Если лицо, принимающее решение, следует предложенным сценариям событийной модели, путь с третьего по пятый пункт может быть уменьшен в четыре раза и займет шесть часов (два часа для сбора информации, три часа для ее анализа и один час на принятие решения) вместо 20-24 часов. То же самое будет происходить на интервале с пятого по седьмой пункт - вместо 24 часов - шесть. Таким образом общее время для локализации эпидемической аварийной ситуации с использованием событийной модели равняется $2+12+6+6+24=50$ часов. Ожидаемое время выигрыша - 36-40 часов. Его можно использовать для предотвращения возникновения сопутствующих инфекций, уменьшения количества контактов и предотвращения распространения паники среди населения.

Выводы. Разработана событийная модель развития эпидемии с учетом причинно-следственных связей между региональными компонентами. Решения таких задач включают в себя использование ситуационного управления и новых информационных технологий. Проведена оценка эффективности разработанной модели. Полученные расчеты показывают, что ожидаемый прирост времени, отведенного на локализацию чрезвычайной эпидемической ситуации, согласно прогнозируемым данным, составляет 36-40 часов.

Ключевые слова: эпидемическая ситуация, событийная модель, локализация, вирусная эпидемия. 